Kidney to Share 
A volume in the series

The Culture and Politics of Health Care Work

Edited by Suzanne Gordon and Sioban Nelson

For a list of books in the series, visit our website at cornellpress.cornell.edu. 


\title{
Kidney to Share
}

\author{
Martha Gershun
}

and John D. Lantos, MD

ILR Press, an imprint of

Cornell University Press

Ithaca and London 
Copyright $(\odot 2021$ by Cornell University

All rights reserved. Except for brief quotations in a review, this book, or parts thereof, must not be reproduced in any form without permission in writing from the publisher. For information, address Cornell University Press, Sage House, 512 East State Street, Ithaca, New York 14850. Visit our website at cornellpress.cornell.edu.

First published 2021 by Cornell University Press

Printed in the United States of America

Library of Congress Cataloging-in-Publication Data

Names: Gershun, Martha, author. | Lantos, John D., author.

Title: Kidney to share / Martha Gershun and John D. Lantos, MD.

Description: Ithaca [New York] : ILR Press, an imprint of Cornell

University Press, 2021. | Series: The culture and politics of health care work | Includes bibliographical references and index.

Identifiers: LCCN 2020056163 (print) | LCCN 2020056164 (ebook) |

ISBN 9781501755439 (hardcover) | ISBN 9781501755453 (pdf) |

ISBN 9781501755446 (epub)

Subjects: LCSH: Gershun, Martha. | Donation of organs, tissues, etc.-

Social aspects. | Donation of organs, tissues, etc.-Moral and ethical aspects. | Organ donors-United States-Biography.

Classification: LCC RD129.5 (print) | LCC RD129.5 (ebook) |

DDC 362.17/83-dc23

LC record available at https://lccn.loc.gov/2020056163

LC ebook record available at https://lccn.loc.gov/2020056164 
For Ann, of blessed memory,

and Cheryl, who paved the way with courage and grace

And Don, who made the mitzvah possible - Martha

For my daughters, Hannah, Tess, and Emma, whose altruism and compassion inspire me -John 
Whoever saves a single life is considered to have saved the whole world. 